\title{
KAJIAN PRA KONDISI DAN KONSENTRASI ASAP CAIR YANG BERBEDA TERHADAP MUTU PRODUK IKAN TEMBANG (Sardinella fimbriata) ASAP CAIR
}

\author{
Krisman Umbu Henggu; \\ Marlon Jusak Rinaldy Benu'; Y Yatris Rambu Tega ${ }^{1}$ \\ 1 Jurusan Teknologi Hasil Perikanan, Fakultas Sains dan Teknologi, Universitas Kristen Wira \\ Wacana Sumba, JI R. Suprapto No. 35, Waingapu, Sumba Timur 87116, NTT, Indonesia \\ 2 Jurusan Teknologi Hasil Perikanan, Fakultas Perikanan dan IImu Kelautan, Universitas Kristen \\ Artha Wacana Kupang, Jl. Adi Sucipto, Kota Kupang 85229, NTT, Indonesia \\ 3 Jurusan Teknologi Hasil Perikanan, Fakultas Perikanan dan Ilmu Kelautan, Universitas Negeri \\ Gorontalo, Jl.Jenderal Sudirman No.06, Kota Gorontalo 96128, Gorontalo, Indonesia \\ *Korespondensi: krismanumbu27@gmail.com \\ (Diterima 05-05-2020; Direvisi 13-05-2020; Dipublikasi 12-06-2020)
}

\begin{abstract}
ABSTRAK
Penelitian ini bertujuan untuk mengetahui pengaruh pra kondisi ikan tembang (Sardinella fimbriata) (kering, kukus, segar) dan konsentrasi asap cair 0,3\%, 0,5\%, 0,7\%, 0,9\%, 1,0\% terhadap karakteristik kimia dan tingkat penerimaan produk ikan tembang (Sardinella fimbriata)asap cair. Penelitian ini dirancang menggunakan Rancangan Acak Kelompok Faktorial (RAKF) dan dianalisis menggunakan ragam ANOVA dua arah. Hasil penelitian menunjukkan kombinasi perlakuan pra kondisi (kering, kukus, segar) dan konsentrasi asap cair yang berbeda menunjukkan tidak berpengaruh nyata terhadap kadar air, akan tetapi memiliki pengaruh terhadap kadar fenol, pH, warna, rasa, aroma dan tekstur produk ikan tembang asap cair. Penerimaan panelis lebih menyukai produk ikan tembang asap cair yang diperoleh dari kombinasi perlakuan pra kondisi kering pada konsentrasi asap cair $1,0 \%$. Karakteristik produk tersebut yakni memiliki tekstur yang kompak/padat, memiliki aroma keasap-asapan yang kuat serta warna kecoklatan yang mengkilap.
\end{abstract}

Kata kunci : Asap cair; Ikan tembang; Kadar air;Kadar fenol;kondisi pH; Mutu organoleptik

\section{Study Pre-conditions and Concentrations of Different Liquid Smoke toward Quality of Sardine Fish (Sardinella fimbriata) Liquid Smoke}

\section{ABSTRACT}

This study aims to determine the effect of pre-condition of sardine fish (Sardinella fimbriata) (dry, steamed, fresh) and liquid smoke concentration of $0.3 \%, 0.5 \%, 0.7 \%, 0.9 \%, 1.0 \%$ toward chemical characteristics and acceptance level of sardine fish (Sardinella fimbriata) liquid smoke products. This research was designed using Factorial Randomized Block Design (RBDF) and analyzed using twoway ANOVA. The results showed the combination to pre-condition treatments (dry, steamed, fresh) and different concentrations of liquid smoke showed not significant effect on water content, but had an influence on phenol levels, pH, color, taste, flavour and texture of liquid smoked fish products. Panelist acceptance preferred liquid smoked fish products obtained from a combination of pre-dry treatment conditions at a liquid smoke concentration of $1.0 \%$. The characteristics of the product are compact/dense texture, strong smoky aroma and shiny brownish color.

Key Words : Hedonic quality; Liquid smoke; Phenol content; pH Conditions; Sardinella fimbriata; Water content. 
PENDAHULUAN

Ikan tembang (Sardinella fimbriata) merupakan kelompok ikan pelagis yang memiliki nilai ekonomis penting di Indonesia karena sejumlah kandungan gizi yang esensial. Data produksi ikan tembang di Indonesia tahun 2018-2019 sebesar 361.844 ton dan perkirakan terus meningkat (KKP 2019). Tingginya jumlah produksi tersebut perlu dilakukan upaya pengolahan, sehingga mampu menjadi sumber protein bagi masyarakat.

Upaya pengolahan ikan tembang di Indonesia untuk skala usaha mikro umumnya ialah ikan asin. Produk tersebut dinilai kurang kompetitif dipasaran karena hanya menghasilkan satu jenis olahan. Oleh sebab itu, upaya diversifikasi produk ikan tembang perlu dilakukan untuk meningkatkan nilai dagang, salah satunya pengasapan. Pengasapan merupakan metode pengolahan ikan yang paling banyak dilakukan di Indonesia (Sulistijowati dkk, 2011).Pengasapan tidak hanya memberikan rasa, warna dan aroma pada ikan, namun berperan sebagai pengawet karena memiliki sifat bakterisida dan antioksidan(Adeyeye 2018).

Proses pengasapan ikan umumnya terdiri atas beberapa metode misalnya pengasapan panas (hot smoking), pengasapan dingin (cold smoking) dan pengasapan cair (liquid smoke) (Sulistijowati $d k k$, 2011). Pengasapan cair (liquid smoke) merupakan metode pengasapan yang relatif sederhana, mudah diaplikasikan dalam segala kondisi, dapat digunakan secara berulang, mengurangi polusi lingkungan dan memiliki senyawa karsinogen yang relatif kecil dibandingkan pengasapan panas (hot smoking) (Lingbeck $d k k, 2014)$.

Berdasarkan sumbernya,asap cair merupakan kondensat senyawa yang dihasilkan dari kayu-kayuan keras melalui penguapan secara simultan yang diikuti oleh penetrasi termal. Proses tersebut dapat dilakukan dengan teknik pirolisis dan kondenisasi (Budaraga dkk, 2016). Asam organik, fenol, furan, piran, aldehid dan keton merupakan senyawa utama pada asap cair yang bertanggung jawab terhadap pembentukan warna, aroma dan citarasa. Selain itu, komponen tersebut dapat berperan sebagai antibakteri dan antioksidan (Montazeri $d k k, 2013)$.

Kajian pengasapan ikan dengan asap cair umumnya dilakukan pada ikan pelagis besar, sedangkan ikan pelagis kecil misalnya ikan tembang masih minimnya kajian tersebut. Oleh sebab itu, penelitian ini bertujuan untuk mengetahui pengaruh pra kondisi (pretreatment) dan konsentrasi asap cair yang berbeda terhadap karakteristik kimia dan tingkat penerimaan produk ikan tembang (Sardinella fimbriata) asap cair. 


\section{METODE PENELITIAN}

\section{Waktu dan Tempat}

Penelitian ini telah dilaksanakan pada bulan Agustus-September 2016. Pembuatan produk ikan tembang asap cair dan pengujian organoleptik (warna, aroma, dan kenampakan) dilakukan di Laboratorium Eksakta Universitas Kristen Artha Wacana Kupang-Nusa Tenggara Timur. Pengujian karakteristik kimia yang meliputi kadar fenol, kadar air dan $\mathrm{pH}$ dilakukan di Laboratorium Biologi Fakultas Sains dan Teknologi, Universitas Nusa Cendana Kupang Nusa Tenggara Timur.

\section{Alat dan Bahan}

Alat yang digunakan dalam pembuatan ikan tembang (Sardinella fimbriata) asap yakni cabinet drayer, talenan, baki, pisau, gelas ukur, pipet dan termometer. Alat yang digunakan dalam analisis organoleptik ialah instrumen petunjuk pengujian berdasarkan Badan Standar Nasional (BSN) 2725.1-2009, sedangkan oven, desikator, statif, $\mathrm{pH}$ meter dan tabung titrasi digunakan untuk menganalisis senyawa fenol, kondisi $\mathrm{pH}$ dan kadar air.

Bahan utama yang digunakan dalam pembuatan ikan tembang asap ialah ikan tembang segar (Sardinella fimbriata) yang diperoleh di pasar tradisional Oeba Kupang dan asap cair hasil pirolisis dari tempurung kelapa koleksi Dr Ayub Meko. Bahan-bahan lain yang digunakan dalam analisis yakni $\mathrm{NaOH}, \mathrm{Na}_{2} \mathrm{~S}_{2} \mathrm{O}_{3}, \mathrm{HCl} 3$ Mdan akuades.

Rancangan percobaan yang diterapkan dalam penelitian ini ialah Rancangan Acak Kelompok (RAK) faktorial (dua faktor). Faktor A meliputi tiga kategori pra kondisi ikan tembang (Sardinella fimbriata) yakni $a_{1}$ (filet ikan tembang kering kemudian direndam dalam asap cair dan dikeringkan), $a_{2}$ (ikan tembang segar/basah lalu direndam dalam asap cair lalu dikeringkan) dan $\mathrm{a}_{3}$ (filet ikan tembang yang dikukus selanjutkan dikeringkan). Sedangkan faktor $B$ meliputi konsentrasi asap cair yang digunakan dalam penelitian ini yakni : $b_{1} \cdot 0,3 \%, b_{2} \cdot 0,5 \%$, $b_{3 .}, 0,7 \%, b_{4} \cdot 0,9 \%$ dan $b_{5} .1,0 \%$.

Data yang diperoleh pada masing-masing variabel pengujian dilakukan uji asumsi, yang meliputi normalitas, dan homogenitas. Data yang telah memenuhi uji asumsi, dilanjutkan uji hipotesis dengan analisis ragam (ANOVA) dua arah dan uji lanjut Duncan jika terdapat pengaruh yang signifikan pada a 0,05 (skala kepercayaan 95\%) (Steel dan Torrie 1995).

\section{Prosedur Penelitian}

Pembuatan ikan tembang (Sardinella fimbiara) asap cair diawali penghilangan kepala dan jeroan, kemudian difilet untuk mendapatkan daging ikan tembang. Filet ikan tembang tersebut dicuci dan direndam dalam larutan garam 5\% selama 25 menit. Proses selanjutnya dilakukan pra kondisi filet ikan 
tembang, yakni filet ikan tembang yang dikeringkan, kukus dan dalam kondisi segar. Setelah proses pra kondisi, masing-masing filet ikan tembang (kondisi kering, kukus, segar) direndam selama 30 menit kedalam masing-masing konsentrasi asap cair 0,3\%, $0,5 \%, 0,7 \%, 0,9 \%$ dan $1,0 \%$. Filet ikan tembang yang telah mendapatkan perlakuan pra kondisi dan perendaman konsentrasi asap cair yang berbeda, selanjutnya dikeringkan dengan cabinet dryer menggunakan kompor gas. Produk ikan tembang asap cair yang dihasilkan dianalisis kimia yang meliputi kadar air (AOAC 2005), fenol (titrasi-AOAC2005), kondisi pH (AOAC 2005) dan penerimaan panelis terhadap karakteristik organoleptik (tekstur, warna, aroma dan rasa) (BSN 2725.12009). Pengujian organoleptik menggunakan panelis terdidik dan semi terlatih sebanyak 30 orang.

\section{HASIL DAN PEMBAHASAN}

\section{Karakteristik Kimia}

\section{Kadar air}

Peranan air pada bahan pangan ialah memelihara tekstur dan cita rasa. Akan tetapi bila keberadaannya melebihi ambang batas standar yang ditetapkan maka bahan pangan tersebut akan cepat mengalami kerusakan. Kadar air produk ikan tembang (Sardinella fimbriata) asap cair yang dihasilkan dari perlakuan pra kondisi filet ikan tembang segar $\left(a_{3}\right)$ memiliki rata-rata kadar tertinggi yakni
$14,22 \%$, pra kondisi kukus $\left(\mathrm{a}_{2}\right) 11,08 \%$, sedangkan produk ikan asap yang dihasilkan dari pra kondisi filet ikan tembang kering $\left(\mathrm{a}_{1}\right)$ memilki kadar air terendah yakni 6,35\%.

Tabel 1 Rerata kadar air ikan tembang (Sardinella fimbriata) asap cair

\begin{tabular}{lcc}
\hline Pra kondisi & $\begin{array}{c}\text { Konsentrasi } \\
\text { asap cair } \\
(\%)\end{array}$ & $\begin{array}{c}\text { Kadar air } \\
(\%)\end{array}$ \\
\hline 1. Ikan & 0,3 & $6,41 \pm 0,08^{\mathrm{a}}$ \\
tembang & 0,5 & $6,46 \pm 0,08^{\mathrm{a}}$ \\
kering $\left(\mathrm{a}_{1}\right)$ & 0,7 & $6,47 \pm 0,12^{\mathrm{a}}$ \\
& 0,9 & $6,23 \pm 0,14^{\mathrm{a}}$ \\
& 1,0 & $6,20 \pm 0,05^{\mathrm{a}}$ \\
\hline 2. Ikan & 0,3 & $11,60 \pm 2,83^{\mathrm{b}}$ \\
tembang & 0,5 & $10,99 \pm 2,78^{\mathrm{b}}$ \\
kukus $\left(\mathrm{a}_{2}\right)$ & 0,7 & $10,96 \pm 3,50^{\mathrm{b}}$ \\
& 0,9 & $10,95 \pm 3,51^{\mathrm{b}}$ \\
& 1,0 & $10,94 \pm 2,46^{\mathrm{b}}$ \\
\hline 3. Ikan & 0,3 & $14,50 \pm 1,40^{\mathrm{c}}$ \\
tembang & 0,5 & $14,51 \pm 1,66^{\mathrm{c}}$ \\
segar $\left(\mathrm{a}_{3}\right)$ & 0,7 & $14,45 \pm 1,94^{\mathrm{c}}$ \\
& 0,9 & $13,89 \pm 2,21^{\mathrm{c}}$ \\
& 1,0 & $13,77 \pm 1,71^{\mathrm{c}}$ \\
\hline
\end{tabular}

Keterangan : Angka yang diikuti oleh huruf yang sama menunjukkan tidak berbeda nyata pada taraf a 0,05 (berlaku pada kolom yang sama).

Hasil analisis ragam ANOVA menunjukkan pengaruh konsentrasi asap cair yang berbeda terhadap kadar air masingmasing perlakuan pra kondisi ikan tidak berpengaruh nyata $(P>0,05)$, sebaliknya perlakuan pra kondisi (kering, kukus, segar) menunjukkan terdapat pengaruh nyata $(P<0,05)$. Hal ini membuktikan bahwa asap cair tidak berkontribusi terhadap sejumlah 
kadar air pada produk, akan tetapi perlakuan pra kondisi yang memberikan pengaruh terhadap keberadaan kadar air ikan tembang asap cair. Pengaruh tersebut diduga akibat pengeringan yang dilakukan sebanyak dua kali pada perlakuan ikan tembang kering $\left(a_{1}\right)$, sehingga sebagian kadar air telah mengalami penguapan.

\section{Kadar Fenol}

Senyawa fenol pada asap merupakan senyawa kumene (aromatik) terkonsentrasi dari alkilasi benzena saat proses pemecahan struktur lignin berlangsung. Rerata kadar fenol masing-masing kombinasi perlakuan pra kondisi dan konsentrasi asap cair yang berbeda berkisar 3,32-6,50 ml/gram. Hasil analisis ragam (ANOVA) menunjukkan pengaruh pra kondisi dan konsentrasi asap cair yang berbeda memberikan pengaruh nyata $(P<0,05)$ terhadap kadar fenol ikan tembang (Sardinella fimbriata) asap cair. Rerata kadar fenol tertinggi yakni 5,20 ml/gram diperoleh pada perlakuan pra kondisi ikan tembang kering $\left(\mathrm{a}_{1}\right)$, sebaliknya perlakuan pra kondisi ikan tembang segar $\left(\mathrm{a}_{3}\right)$ memiliki rerata kadar fenol terendah yakni 4,53 $\mathrm{ml} / \mathrm{gram}$. Tingginya konsentrasi fenol pada pra kondisi ikan tembang kering $\left(\mathrm{a}_{1}\right)$ akibat kondisi fisik ikan yang relatif higrokopis sehingga penyerapan dan penetrasi asap cair cukup tinggi, sedangkan pada pra kondisi ikan tembang segar $\left(a_{3}\right)$ dan kukus $\left(a_{2}\right)$ relatif rendah akibat masih tersedia sebagian kadar air sehingga menyebabkan kesetimbangan dan mempengaruhi rendahnya laju penetrasi fenol. Menurut Mujumdar (2007) kondisi bahan pangan yang cenderung kering akan memudahkan proses penyerapan senyawasenyawa yang terdapat pada fase cairan kedalam bahan pangan.

Tabel 2 Rerata kadar fenol ikan tembang (Sardinella fimbriata) asap cair

\begin{tabular}{|c|c|c|}
\hline Pra kondisi & $\begin{array}{c}\text { Konsentrasi } \\
\text { asap cair } \\
(\%)\end{array}$ & $\begin{array}{c}\text { Kadar } \\
\text { fenol } \\
\text { (ml/gram) }\end{array}$ \\
\hline \multirow{5}{*}{$\begin{array}{l}\text { 1. Ikan tembang } \\
\text { kering }\left(\mathrm{a}_{1}\right)\end{array}$} & 0,3 & $4,14 \pm 0,93^{a}$ \\
\hline & 0,5 & $4,04 \pm 0,12^{b}$ \\
\hline & 0,7 & $5,81 \pm 0,16^{b}$ \\
\hline & 0,9 & $5,51 \pm 0,21^{c}$ \\
\hline & 1,1 & $6,50 \pm 0,04^{c}$ \\
\hline \multirow{5}{*}{$\begin{array}{l}\text { 2. Ikan tembang } \\
\text { kukus }\left(\mathrm{a}_{2}\right)\end{array}$} & 0,3 & $3,97 \pm 0,31^{a}$ \\
\hline & 0,5 & $4,92 \pm 0,47^{b}$ \\
\hline & 0,7 & $5,33 \pm 0,69 b$ \\
\hline & 0,9 & $5,70 \pm 0,25^{c}$ \\
\hline & 1,1 & $6,06 \pm 0,20 c$ \\
\hline \multirow{5}{*}{$\begin{array}{l}\text { 3. Ikan tembang } \\
\text { segar }\left(\mathrm{a}_{3}\right)\end{array}$} & 0,3 & $3,23 \pm 0,88^{a}$ \\
\hline & 0,5 & $4,86 \pm 0,11^{b}$ \\
\hline & 0,7 & $4,51 \pm 0,08^{b}$ \\
\hline & 0,9 & $4,65 \pm 0,54$ \\
\hline & 1,1 & $5,40 \pm 0,49 c$ \\
\hline Keterangan : & olom yans & $\begin{array}{l}\text { eh huruf yang } \\
\text { tidak berbeda } \\
0,05 \text { (berlaku } \\
\text { na). }\end{array}$ \\
\hline
\end{tabular}

Konsentrasi asap cair yang berbeda terhadap masing-masing pra kondisi ikan tembang turut memberikan pengaruh signifikan terhadap peningkatan kadar fenol. Rata-rata peningkatan kadar fenol pada masing-masing perlakuan konsentrasi asap 
cair yakni 0,37-1,46 ml/gram. Hal serupa juga dilaporkan oleh Hutomo dkk, (2015) penggunaan konsentrasi asap cair yang cenderung meningkat pada belut (Monopterus albus) memiliki korelasi positif terhadap kandungan fenol. Ardianto dkk, (2014) penggunaan konsentrasi asap cair 2\%, 3\% dan 4\% pada pengolahan ikan Arabushi ikan tongkol (Euthynus affinis) menghasilkan peningkatan kadar fenol secara berturut $0,08 \%, 0,15 \%$ dan $0,18 \%$.

\section{Kondisi pH}

Kondisi pH didefinisikan sebagai derajat keasaman yang terkandung dalam bahan pangan. Rerata kondisi $\mathrm{pH}$ ikan tembang (Sardinella fimberiata) asap cair berkisar pada pH asam 3,14 hingga hampir mencapai netral yakni 6,40. Rerata nilai pH tertinggi yakni 6,00 diperoleh pada perlakuan pra kondisi ikan tembang segar $\left(\mathrm{a}_{3}\right)$, perlakuan ikan tembang kukus $\left(\mathrm{a}_{2}\right)$ mencapai 5,40 . Sedangkan nilai $\mathrm{pH}$ terendah yakni 4,91 diperoleh pada perlakuan pra kondisi ikan tembang kering $\left(a_{1}\right)$.Penurunan $\mathrm{pH}$ ikan tembang asap cair juga terjadi seiring peningkatan konsentrasi asap cair. Hal ini diduga terkonsentrasinya senyawa asam misalnya golongan asam karboksilat (furfural dan asam asetat glacial) pada asap cair.
Tabel 3 Rerata nilai pH ikan tembang (Sardinella fimbriata) asap cair

\begin{tabular}{lcr}
\hline Pra kondisi & $\begin{array}{c}\text { Konsentrasi } \\
\text { asap cair } \\
(\%)\end{array}$ & Nilai pH \\
\hline 1. Ikan tembang & 0,3 & $4,40 \pm 0,55^{\mathrm{a}}$ \\
kering $\left(\mathrm{a}_{1}\right)$ & 0,5 & $5,65 \pm 0,11^{\mathrm{b}}$ \\
& 0,7 & $5,65 \pm 0,08^{\mathrm{b}}$ \\
& 0,9 & $4,33 \pm 0,54^{\mathrm{c}}$ \\
& 1,1 & $4,51 \pm 0,49^{\mathrm{c}}$ \\
\hline 2. Ikan tembang & 0,3 & $6,97 \pm 0,31^{\mathrm{a}}$ \\
kukus $\left(\mathrm{a}_{2}\right)$ & 0,5 & $4,92 \pm 0,47^{\mathrm{b}}$ \\
& 0,7 & $5,33 \pm 0,69^{\mathrm{b}}$ \\
& 0,9 & $5,70 \pm 0,25^{\mathrm{c}}$ \\
& 1,1 & $4,06 \pm 0,20^{\mathrm{c}}$ \\
\hline 3. Ikan tembang & 0,3 & $6,14 \pm 0,93^{\mathrm{a}}$ \\
segar $\left(\mathrm{a}_{3}\right)$ & 0,5 & $6,04 \pm 0,12^{\mathrm{b}}$ \\
& 0,7 & $5,81 \pm 0,16^{\mathrm{b}}$ \\
& 0,9 & $6,51 \pm 0,21^{\mathrm{c}}$ \\
& 1,1 & $5,50 \pm 0,04^{\mathrm{c}}$ \\
\hline & Angka yang dikuti oleh huruf yang \\
& sama menunjukkan tidak berbeda \\
& nyata pada taraf a 0,05 (berlaku \\
pada kolom yang sama).
\end{tabular}

Hasil analisis ragam (ANOVA) (Tabel 3) menunjukkan pengaruh pra kondisi dan konsentrasi asap cair yang berbeda memberikan pengaruh nyata $(P<0,05)$ terhadap nilai $\mathrm{pH}$ ikan tembang (Sardinella fimbriata) asap cair. Hasil analisis tersebut menunjukkan bahwa asap cair memberikan kontribusi terhadap penurunan $\mathrm{pH}$ ikan tembang asap cair. Parnanto dan Utami (2009) penggunaan asap cair 25\%, 30\% dan 35\% pada ikan tongkol menunjukkan trend penurunan $\mathrm{pH}$ seiring meningkatnya konsentrasi asap cair. Penurunan $\mathrm{pH}$ pada produk ikan tembang (Sardinella fimbriata) 
diduga dapat menekan pertumbuhan mikroba pembusuk,namun pengujian mikrobiologi pada produk ikan tembang (Sardinella fimbriata) asap cair belum dilakukan.

\section{Mutu Organoleptik}

\section{Tekstur}

Tingkat penerimaan panelis terhadap tekstur ikan tembang asap cair ialah pada taraf agak suka hingga pada sangat suka. Rerata penerimaan panelis pada pra kondisi kukus yakni agak suka, sedangkan pada pra kondisi kering dan segar penerimaan panelis memilih atribut suka hingga pada sangat suka. Hal ini diduga akibat kondisi tekstur ikan pada pra kondisi pengukusan cenderung hancur saat perebusan. Sumiati (2008) menyatakan aktivitas perebusan pada ikan menyebabkan tendon ikan menjadi putus sehingga kondisi fisik terutama tekstur daging menjadi rusak (wholesomeness).

Hasil analisis ragam (ANOVA) (Tabel 4) menunjukkan masing-masing pra kondisi ikan tembang kering $\left(a_{1}\right)$, kukus $\left(a_{2}\right)$, segar $\left(a_{3}\right)$ memiliki pengaruh nyata $(P<0,05)$ terhadap tekstur, akan tetapi perlakuan asap cair tidak memberikan pengaruh nyata $(P>0,05)$ terhadap penerimaan panelis pada tekstur ikan tembang asap cair. Hal serupa juga dilaporkan oleh Ghazali dan Swastawati (2014) penggunaan asap cair tidak memberikan pengaruh nyata terhadap tekstur ikan manyung (Arius thalassinus) asap yang diolah dengan pengasapan smoking cabinet dan asap cair.

\section{Warna}

Penerimaan panelis terhadap tampilan warna ikan tembang asap cair yakni agak suka hingga pada sangat suka. Rata-rata panelis lebih menyukai ikan tembang asap cair yang diolah dengan pra kondisi kering yakni ikan tembang terlebih dahulu dikeringkan, kemudian direndam dalam asap cair. Hal serupa juga pada pra kondisi ikan tembang segar, akan tetapi pada produk ikan tembang asap cair yang diolah dengan pra kondisi pengukusan dan pengasapan cair yang berbeda penerimaan panelis hanya pada taraf agak suka hingga pada suka. Indikator penerimaan panelis didasarkan pada intensitas warna kecoklatan pada produk ikan tembang asap cair. Intensitas warna yang dihasilkan oleh produk tersebut diduga akibat penetrasi asap cair. Hal ini dapat dilihat pada produk ikan tembang asap cair yang memiliki kandungan fenol tertinggi (Tabel 2) memiliki intensitas warna kecoklatan yang lebih mengkilap.

Hasil analisis ragam (ANOVA) (Tabel 4) menunjukkan perlakuan pra kondisi ikan tembang kering $\left(\mathrm{a}_{1}\right)$, ikan tembang kukus $\left(\mathrm{a}_{2}\right)$ dan ikan tembang segar $\left(a_{3}\right)$ memiliki pengaruh nyata $(P<0,05)$ terhadap warna produk ikan tembang asap cair. 
Tabel 4 Rerata tingkat penerimaan organoleptik (tekstur, warna, aroma dan rasa) ikan tembang (Sardinella fimbriata) asap cair

\begin{tabular}{|c|c|c|c|c|c|}
\hline \multirow[t]{2}{*}{ Pra kondisi } & \multirow{2}{*}{$\begin{array}{c}\text { Konsentrasi } \\
\text { asap cair (\%) }\end{array}$} & \multicolumn{4}{|c|}{ Organoleptik } \\
\hline & & Tekstur & Warna & Aroma & Rasa \\
\hline \multirow{5}{*}{$\begin{array}{l}\text { 1. Ikan tembang kering } \\
\text { (a1) }\end{array}$} & 0,3 & $4 \pm 0,05^{b}$ & $4 \pm 0,03^{b}$ & $4 \pm 0,02^{b}$ & $3 \pm 0,01^{a}$ \\
\hline & 0,5 & $4 \pm 0,06^{b}$ & $5 \pm 0,03 c$ & $4 \pm 0,03^{b}$ & $3,5 \pm 0,01^{a b}$ \\
\hline & 0,7 & $4,5 \pm 0,05^{b}$ & $5 \pm 0,01 c$ & $4 \pm 0,03^{b}$ & $4 \pm 0,05^{b}$ \\
\hline & 0,9 & $5 \pm 0,03 c$ & $5 \pm 0,03 c$ & $4,5 \pm 0,01^{c}$ & $5 \pm 0,07 c$ \\
\hline & 1,1 & $5 \pm 0,03^{c}$ & $5 \pm 0,05^{c}$ & $5 \pm 0,01^{d}$ & $5 \pm 0,01^{c}$ \\
\hline \multirow{5}{*}{$\begin{array}{l}\text { 2. Ikan tembang kukus } \\
\left(\mathrm{a}_{2}\right)\end{array}$} & 0,3 & $3 \pm 0,01^{a}$ & $3 \pm 0,05^{a}$ & $3,5 \pm 0,05^{\mathrm{ab}}$ & $3 \pm 0,02^{a}$ \\
\hline & 0,5 & $3 \pm 0,04^{a}$ & $3 \pm 0,03^{a}$ & $4 \pm 0,05^{b}$ & $3 \pm 0,05^{a}$ \\
\hline & 0,7 & $3 \pm 0,04^{a}$ & $3 \pm 0,03^{a}$ & $4 \pm 0,02^{b}$ & $4 \pm 0,05^{b}$ \\
\hline & 0,9 & $3 \pm 0,04^{a}$ & $4 \pm 0,03^{b}$ & $4,5 \pm 0,05^{c}$ & $4,5 \pm 0,03^{b c}$ \\
\hline & 1,1 & $3 \pm 0,01^{\text {a }}$ & $4 \pm 0,01^{b}$ & $5 \pm 0,07^{d}$ & $5 \pm 0,03 c$ \\
\hline \multirow{5}{*}{$\begin{array}{l}\text { 3. Ikan tembang segar } \\
\left(\mathrm{a}_{3}\right)\end{array}$} & 0,3 & $3,5 \pm 0,01^{b}$ & $4 \pm 0,05^{b}$ & $3 \pm 0,05^{a}$ & $3 \pm 0,05^{a}$ \\
\hline & 0,5 & $4 \pm 0,47^{b}$ & $4 \pm 0,05^{b}$ & $3 \pm 0,05^{a}$ & $3 \pm 0,05^{a}$ \\
\hline & 0,7 & $4,5 \pm 0,06^{b}$ & $4,5 \pm 0,02^{b}$ & $4 \pm 0,03^{b}$ & $4 \pm 0,03^{b}$ \\
\hline & 0,9 & $4,5 \pm 0,05^{b}$ & $5 \pm 0,05^{c}$ & $4 \pm 0,03^{b}$ & $4 \pm 0,03^{b}$ \\
\hline & 1,1 & $4,5 \pm 0,05^{b}$ & $5 \pm 0,03^{c}$ & $4 \pm 0,01^{b}$ & $4,5 \pm 0,03^{c}$ \\
\hline
\end{tabular}

Keterangan: Angka yang diikuti oleh huruf yang sama menunjukkan tidak berbeda nyata pada taraf $a$ 0,05 (berlaku pada kolom yang sama).

Keterangan atribut mutu : $\quad 1=$ tidak suka, $2=$ biasa atau netral, $3=$ agak suka, $4=$ suka, $5=$ sangat suka

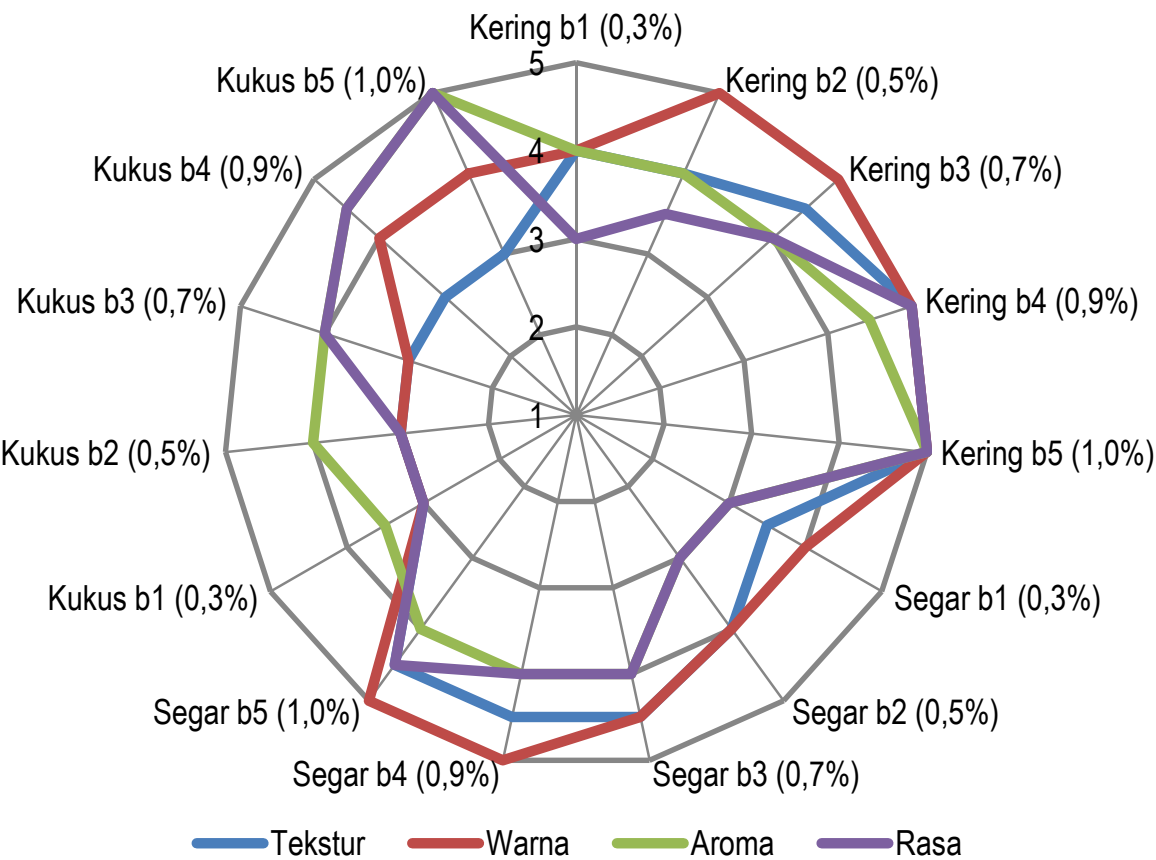

Gambar 1 Grafik sebaran penerimaan panelis terhadap keseluruhan karakteristik organoleptik (tekstur, warna, aroma,rasa) ikan tembang (Sardinella fimbriata) asap cair.

Keterangan atribut mutu: $\quad 1=$ tidak suka, 2 = biasa atau netral, $3=$ agak suka, $4=$ suka

$5=$ sangat suka

http://ejurnal.ung.ac.id/index.php/jfpj/issue/archive 
Pra kondisi ikan tembang kering dan segar memiliki warna cokelat yang lebih mengkilap dibandingkan produk ikan asap cair yang diolah dengan pra kondisi pengukusan yang memilki kenampakan kusam akibat perebusan. Girrad (1992) kecoklatan pada produk ikan asap disebabkan oleh senyawa karbonil terutama glikoldehid dan metilglioksal pada asap cair yang berinteraksi dengan gugus asam amino melalui reaksi mailard. Senyawa asap berpenetrasi pada bagain tubuh ikan sehingga menghasilkan lapisan damar tiruan yang beriteraksi dengan oksigen dan membentuk warna coklat keemasan.

\section{Aroma}

Produk ikan tembang asap cair dengan pengolahan pra kondisi ikan tembang kering (a 1 ) memiliki tingkat penerimaan paling disukai dibandingkan produk ikan tembang asap cair yang dihasilkan dari pra kondisi pengukusan $\left(a_{2}\right)$ dan segar $\left(a_{3}\right)$. Hal ini diduga akibat pra kondisi ikan tembang kering yang memiliki sifat higrokopis sehingga penetrasi asap cair cenderung lebih tinggi dibandingkan pra kondisi ikan segar dan pengukusan. Tingginya penetrasi asap cair tersebut terkonfirmasi oleh tingginya senyawa fenol pada perlakuan pra kondisi ikan tembang kering (Tabel 2).

Hasil analisis sidik ragam (ANOVA) menunjukkan perlakuan pra kondisi dan konsentrasi asap cair yang berbeda memberikan pengaruh nyata $(P<0,05)$ terhadap aroma produk ikan tembang asap cair. Hal ini menunjukkan bahwa komponen kimia yang terkandung dalam asap cair sangat berpengaruh terhadap intensitas aroma produk ikan tembang asap cair. Kecenderungan penerimaan panelis juga menunjukkan trend peningkatan seiring meningkatnya konsentrasi asap cair (Tabel 4). Peningkatan penerimaan panelis tersebut diduga akibat terkonsentrasinya senyawa yang terkandung dalam asap terutama senyawa fenol. Chambers dkk, (1998) senyawa fenol misalnya 2,6-dimethoxyphenol, 4-ethyguaiacol, thymol, guaiacol dan carvacrol merupakan senyawa yang bertanggungjawab terhadap pembentukan flavour keasapasapan.

\section{Rasa}

Penerimaan panelis terhadap rasa produk ikan tembang asap cair yakni pada skala atribut agak suka hingga pada sangat suka. Rata-rata panelis lebih menyukai produk tembang asap cair yang diolah dengan perlakuan pra kondisi kering dibandingkan perlakuan pengukusan dan kondisi segar. Hal ini diduga akibat penetrasi asap cair pada pra kondisi ikan tembang kering. Hasil analisis sidik ragam (ANOVA) menunjukkan kombinasi perlakuan pra kondisi dan konsentrasi asap cair yang berbeda berpengaruh nyata $(P<0,05)$ terhadap rasa ikan tembang asap cair. Penerimaan panelis terhadap rasa produk 
ikan tembang asap cair umumnya lebih menyukai produk yang dihasilkan dari pengolahan pra kondisi ikan tembang kering $\left(a_{1}\right)$, selain itu kecenderungan tingkat kesukaan panelis meningkat seiring penggunaan konsentrasi asap cair pada konsentrasi yang lebih tinggi (Tabel 4). Tingkat kesukaan tersebut disebabkan oleh rasa keasap-asapan yang ditimbulkan oleh asap cair. Kim dan Fujimaki (1974) senyawasenyawa mayor turunan fenol misalnya Syringol, Dimethylphenol, 4-methylguaiacol, Isoeugenol ,o-Cresol, xylenol, 2-Ethyl-5methylphenol, Guaicol, 2,6-Dimethoxyphenol dan Pyrocatechol merupakan senyawa utama pembentukan rasa asap/kesan terbakar, kresol, manis dan pedas.

\section{KESIMPULAN}

Pengaruh kombinasi perlakuan pra kondisi dan konsentrasi asap cair yang berbeda tidak memberikan pengaruh terhadap kadar air, namun memilki pengaruh terhadap kadar fenol, pH, warna, rasa, aroma dan tekstur produk ikan tembang asap cair. Tingkat penerimaan panelis lebih menyukai produk ikan tembang asap cair yang diperoleh dari kombinasi perlakuan pra kondisi kering pada konsentrasi asap cair 1,0\%. Tingkat kesukaan tersebut didasarkan pada tekstur produk ikan tembang asap cair yang kompak/padat, memiliki aroma keasap-asapan yang kuat serta warna kecoklatan yang mengkilap.

\section{DAFTAR PUSTAKA}

[AOAC] Association of Official Analytical Chemist. 2005. Official Method of Analysis of The Association of Official Analytical of Chemist. Arlington (US): The Association of Official Analytical Chemist, Inc.

Adeyeye, S.A.O. 2018. Smoking of fish: a critical review. Journal of Culinary Science \& Technology: 1:17.

Ardianto, C., Swastawati, F., Riyadi, P.H. 2014. Pengaruh perbedaan konsentrasi asap cair terhadap karakteristik arabushi ikan tongkol (Euthynus affinis). Jurnal Pengolahan dan Bioteknologi Hasil Perikanan. 3(4):1015.

[BSN] Badan Standardisasi Nasional. 2009. Ikan Asap-Bagian Spesifikasi. Jakarta (ID): Departemen Perindustrian RI. SNI2725.1-2009

Budaraga, K., Marlida, Y., Bulanin, U.. 2016. Liquid smoke production quality from raw materials variation and different pyrolysis temperature. Journal on Advanced Science, Engineering and Information Technology. 6(3): 306-315.

Chambers, D.H., Chambers, E., Seitz, L.M., Sauer, D.B., Robinson, K., Allison, A.A. 1998. Sensory characteristics of chemical compounds potentially associated with smoky aroma in foods. Developments in Food Science. 40: 187-194.

Ghazali, R.R., Swastawati, F. 2014. Analisa tingkat keamanan ikan manyung (Arius Thalassinus) asap yang diolah dengan metode pengasapan berbeda. Jurnal Pengolahan dan Bioteknologi Hasil Perikanan. 3(4): 31-38.

Hutomo, H.D., Swastawati, F., Rianingsih, L. 2015. Pengaruh konsentrasi asap cair terhadap kualitas dan kadar kolesterol 
belut (Monopterus albus) asap. Jurnal Pengolahan dan Bioteknologi Hasil Perikanan. 4(1): 7-14.

Kim, K., Kurata, T., Fujimaki, M. 1974. Identification of flavor constituents in carbonyl, non-carbonyl neutral and basic fractions of aqueous smoke condensates. Agricultural and Biological Chemistry. 38(1): 53-63.

[KKP] Kementerian Kelautan dan Perikanan. 2019. Produktivitas Perikanan Indonesia Jakarta (ID): Kementerian Kelautan dan Perikanan

Lingbeck, J.M., CorderoP, O'Bryan, C.A., Johnson, M.G., Ricke, S.C., Crandall, P.G. 2014. Functionality of liquid smoke as an all-natural antimicrobial in food preservation. Meat Science.97(2):197206.

Montazeri, N., Oliveira, A.C., Himelbloom, B.H., Leigh, M.B., Crapo, C.A. 2013. Chemical characterization of commercial liquid smoke products. Food Science dan Nutrition. 1(1):102-115.

Mujumdar, Arun, S. 2007. Handbook of Industrial Drying. Boca Raton (FL): CRC Press

Parnanto, N.H.R., Utami, R. 2009. Potensi asap cair tempurung kelapa sebagai alternatif pengganti hidrogen peroksida $\left(\mathrm{H}_{2} \mathrm{O}_{2}\right)$ dalampengawetan ikan tongkol (Euthynnus affinis). Jurnal Teknologi Hasil Pertanian. 2(2): 94-103.

Riansyah, A., Supriadi, A., Nopianti, R. 2013. Pengaruh perbedaan suhu dan waktu pengeringan terhadap karakteristik ikan asin sepat siam (Trichogaster pectoralis) dengan menggunakan oven. Jurnal Fishtech. 2(1): 53-68.

Steel, R.G.D., Torrie, J.H. 1995. Prinsip Dan Prosedur Statistika. Penterjemah:
Bambang Sumantri. Jakarta (ID): Gramedia Pustaka.

Sulistijowati, R.S., Djunaedi, O.S., Nurhajati, J., Afrianto E., Udin, Z. 2011. Mekanisme Pengasapan lkan. Bandung (ID): UNPAD Press

Sumiati. 2008. Pengaruh pengolahan terhadap mutu cerna protein ikan mujair(Tilapia mossambica) [skripsi]. Bogor (ID): Institut Pertanian Bogor. 